\title{
HUBUNGAN TINGKAT KEPARAHAN GINGIVITIS DENGAN DERAJAT HIPERTENSI DI POLI GIGI RUMAH SAKIT UMUM PUSAT H ADAM MALIK MEDAN
}

\author{
${ }^{1)}$ Sri Utami, ${ }^{2)}$ Ngena Ria, ${ }^{3)}$ Herlinawati \\ ${ }^{1}$ Jurusan Keperawatan Poltekkes Medan \\ 2,3 Jurusan Keperawatan Gigi Poltekkes Medan
}

\begin{abstract}
Abstrak
Hipertensi adalah peningkatan tekanan sistolik dan diastolik darah arteri. Manifestasi oral dari hipertensi secara klinis kurang dapat dikenali, namun sering menimbulkan efek gingivitis. Perdarahan gusi atau gingival, merupakan tanda awal dari inflamasi pada gingival yang dikenal dengan gingivitis. Penelitian ini bertujuan untuk mengetahui hubungan tingkat keparahan gingivitis dengan derajat hipertensi menggunakan metode analitik dengan rancangan cross sectional. Subyek penelitian adalah pasien gingivitis disertai hipertensi di Poli Gigi RSUP H Adam Malik Medan. Pengambilan sampel menggunakan teknik consecutive sampling. Jumlah sampel sesuai kriteria inklusi dalam kurun waktu 24 hari hari buka berjumlah 60 pasien gingivitis dengan hipertensi. Data yang dikumpulkan adalah tingkat keparahan gingivitis diperoleh dengan mengukur perdarahan gingival menggunakan prob menghasilkan Papilla Bleeding Index (PBI) dan derajat hipertensi diukur dengan tensimeter air raksa. Data dianalisa menggunakan sistem komputerisasi. Hubungan tingkat keparahan gingivitis dengan dengan derajat hipertensi menggunakan uji Spearman pada tingkat kepercayaan $95 \%$. Hasil penelitian diperoleh nilai $\mathrm{p}=0,013$ maka terdapat hubungan yang bermakna antara tingkat keparahan gingivitis dengan derajat hipertensi. Kekuatan hubungan menunjukkan hubungan yang sedang dengan nilai $\mathrm{r}=0,336$ dan berpola positif. Dari persamaan garis dapat diprediksi bahwa pada tingkat gingivitis ringan $(\mathrm{PBI}=1)$ akan terjadi hipertensi derajat $\mathrm{I}(140-159 \mathrm{mmHg} / 90-99 \mathrm{mmHg})$. Disarankan agar hasil penelitian ini dapat dijadikan sumber informasi dan referensi adanya hubungan yang bermakna antara gingivitis dengan hipertensi di perpustakaan Politeknik Kesehatan Kemenkes Medan.dan RSUP H Adam Malik Medan
\end{abstract}

Kata kunci : Gingivitis, Hipertensi

\section{PENDAHULUAN}

\section{Latar Belakang}

Hipertensi atau tekanan darah tinggi adalah kondisi medis kronis dengan peningkatan tekanan darah arteri yang berada di atas nilai ambang tertentu. Peningkatan ini menyebabkan jantung harus bekerja lebih keras dari keadaan biasanya untuk mengedarkan darah melalui pembuluh darah. Hipertensi mengindikasikan adanya risiko kardiovaskuler yang berhubungan dengan peningkatan tekanan darah.

Sesuai tabel Klasifikasi Joint National Committee (JNC7) dalam Iqbal (2011). pada orang berusia 18 tahun ke atas, hipertensi didefinisikan sebagai pengukuran tekanan darah sistolik dan/atau diastolik yang terusmenerus melebihi nilai normal. Dalam batas normal tekanan sistolik (90-119) mmHg dan diastolik (6079) $\mathrm{mmHg}$. Pra-hipertensi adalah kondisi pada tekanan darah sistolik (120-139) $\mathrm{mmHg}$ dan diastolik (80-89) mmHg. Selanjutnya hipertensi dibedakan menjadi Hipertensi Derajat I (satu) pada tekanan darah sistolik
(140-159) $\mathrm{mmHg}$ dan diastolik (90-99) mmHg, Hipertensi Derajat II (dua) dengan tekanan darah sistolik $\geq 160$ $\mathrm{mmHg}$ tekanan diastolik $\geq 100 \mathrm{mmHg}$.

Menurut Doniger (2005), seseorang yang mengalami hipertensi dapat terjadi kerusakan organ-organ tubuh seperti ginjal, jantung, otak dan mata. Hipertensi juga sebagai faktor utama risiko terjadi stroke, infark miokard, aneurisma arteri, penyakit arteri perifer, dan penyebab penyakit ginjal kronik. Bahkan peningkatan tekanan darah arteri terkait dengan harapan hidup yang lebih pendek.

Menurut World Health Organization (WHO) hipertensi sebagai penyebab utama kematian di dunia yaitu sekitar 12,8\% atau lebih dari tujuh juta manusia per tahun. Berdasarkan penelitian Sikkerimath SB dkk (2010) menyatakan bahwa prevalensi hipertensi di Rumah Sakit Gigi dan Mulut Bagalkot, India adalah 20,6\%

Peningkatan tekanan arteri merupakan masalah kesehatan yang penting di negara berkembang. Dalam keadaan normal tekanan darah sistolik kurang dari 120 $\mathrm{mmHg}$ dan tekanan darah diastolik kurang dari $80 \mathrm{mmHg}$. 
Pada pasien yang diduga mengalami hipertensi memiliki tekanan darah sistolik lebih besar dari $140 \mathrm{mmHg}$ dan tekanan darah diastolik lebih besar dari $90 \mathrm{mmHg}$. Gejala yang dapat diduga dari hipertensi adalah pusing, sakit kepala, kelelahan, dan tinnitus, tetapi hipertensi umumnya asimptomatik

Di Indonesia masalah hipertensi cenderung meningkat. Hasil Survei Kesehatan Rumah Tangga (SKRT) tahun 2001 menunjukkan 8,3\% penduduk menderita hipertensi dan menurut Survei Kesehatan Nasional (SKN) 2004 meningkat menjadi 27,5\%. Berdasarkan hasil Riset Kesehatan Dasar (RISKESDAS) tahun 2007, menunjukkan prevalensi hipertensi di Indonesia adalah $32,2 \%$.

Secara klinis didalam mulut tidak ada manifestasi yang diakibatkan langsung dari hipertensi tetapi penggunaan obat-obatan antihipertensi sering menimbulkan efek samping. Penggunaan obat-obatan antihipertensi dapat menimbulkan manifestasi oral, seperti serostomia, pembesaran gingival, periodontitis, facial paralisis dan gingivitis.

Gingivitis adalah salah satu penyakit umum yang dapat terjadi pada pasien hipertensi dengan tampilan klinis perdarahan gingival. Berdasarkan Third Nasional Epidemiological Survey on Oral Health in China (2008) menunjukkan bahwa 14,5\% pada populasi kelompok umur 35-44 tahun mempunyai periodontal yang sehat, sekitar 77,3\% perdarahan gingival. Pada kelompok umur 65-74 tahun sebesar $14,1 \%$ tidak menunjukkan penyakit periodontal, dan sebesar $68 \%$ terjadi perdarahan gingiva.

Perdarahan gingiva merupakan tanda klinis dari inflamasi gingiva yang dapat diperiksa melalui probe dan nilai dengan Papilla Bleeding Index (PBI).(Dalimunthe, 2005). Penelitian yang dilakukan Kumar dkk (2012), sebanyak $85,38 \%$ pasien hipertensi mengalami perdarahan gingival melalui probing dengan karakteristik kemerahan pada tepi gingival bebas. Hasil penelitian Golebiewska dkk (2006) diketahui bahwa pendarahan gingival pada pasien hipertensi yang dirawat di rumah sakit sebesar $25,53 \%$, dan berdasarkan penelitian Vidal dkk (2011) menunjukkan $33,7 \%$ pendarahan gingival saat probing terjadi pada pasien hipertensi yang mengkonsumsi obat anti hipertensi. Data bulan Januari sampai dengan Desember tahun 2013 di Poli Gigi RSUP H Adam Malik Medan, jumlah kunjungan mencapai 4.580 pasien dengan rata-rata 382 pasien perbulan, namun tidak diketahui prevalensi gingivitis dengan hipertensi.

Berdasarkan uraian diatas, diduga hipertensi dapat terjadi pada pasien gingivitis. Beberapa penelitian menyimpulkan terdapat hubungan antara perdarahan gingival saat probing pada pasien hipertensi yang mengkonsumsi obat antihipertensi. Banyak juga peneliti melaporkan ada hubungan antara periodontitis atau gingivitis dengan meningkatnya risiko penyakit kardiovaskuler, namun beberapa peneliti lain menyatakan tidak adanya bukti-bukti terhadap kesimpulan tersebut (Wangsarahardja, 2005).

Adanya perbedaan hasil penelitian yang berkaitan dengan infeksi periodontal dan penyakit kardiovaskuler, maka perlu dilakukan penelitian lebih lanjut. Oleh karena itu peneliti tertarik untuk melakukan penelitian terhadap pasien gingivitis yang mengalami hipertensi

\section{Perumusan Masalah}

Berdasarkan uraian diatas hasil penelitian mengindikasikan adanya hubungan infeksi periodontal dengan penggunaan obat-obatan antihipertensi. Sedangkan di Rumah Sakit Gigi dan Mulut Bagalkot India tedeteksi 20,6\% prevalensi hipertensi. Sebagian peneliti mendukung konsep peran penyakit periodontal atau gingival sebagai faktor risiko terjadinya penyakit jantung koroner, walaupun peneliti lainnya menyatakan sebaliknya.

Oleh karenanya akan diteliti, adakah hubungan antara gingivitis dengan hipertensi sebagai faktor risiko penyakit kardiovaskuler.

\section{Tujuan Penelitian}

Tujuan Umum

Penelitian dilakukan untuk mengetahui hubungan gingivitis dengan hipertensi di Poli Gigi Rumah Sakit Umum Pusat H Adam Malik Medan.

Tujuan Khusus

1. Dapat diketahui proporsi gingivitis pada katagori ringan, sedang, dan parah di Poli Gigi Rumah Sakit Umum Pusat H Adam Malik Medan.

2. Dapat diketahui proporsi hipertensi pada katagori pra-hipertensi, hipertensi derajat I, dan hipertensi derajat II di Poli Gigi Rumah Sakit Umum Pusat H Adam Malik Medan.

3. Dapat diketahui kekuatan hubungan gingivitis dengan hipertensi di Poli Gigi Rumah Sakit Umum Pusat H Adam Malik Medan.

\section{Manfaat Penelitian}

1. Bagi pasien di Poli Gigi Rumah Sakit Umum Pusat $\mathrm{H}$ Adam Malik Medan sebagai bahan informasi agar dapat menjaga kesehatan mulut dan gigi untuk mencegah terjadnya gingivitis sebagai faktor risiko hipertensi.

2. Bagi institusi pendidikan kesehatan, laporan hasil penelitian sebagai bahan rujukan dan referensi di Perpustakaan Terpadu Politeknik Kesehatan Kemenkes Medan

3. Bagi peneliti lain, hasil penelitian dapat menjadi sumber data untuk penelitian lanjutan

\section{METODOLOGI PENELITIAN}

\section{Lokasi dan Waktu Penelitian}

Penelitian dilakukan di Poli Gigi Rumah Sakit Umum Pusat H Adam Malik Medan.dilaksanakan pada bulan Juli sampai dengan bulan Oktober 2014.

\section{Desain Penelitian}

Penelitian dilakukan menggunakan desain cross sectional dengan pendekatan hubungan dua variabel antara tingkat keparahan gingivitis dengan derajat hipertensi. 


\section{Populasi dan Sampel Penelitian}

Populasi

Populasi dalam penelitian ini adalah pasien gingivitis dengan hipertensi di Poli Gigi Rumah Sakit Umum Pusat H Adam Malik Medan.

Sampel

Sampel penelitian berjumlah 60 orang pasien gingivitis disertai hipertensi yang memenuhi kriteria inklusi dengan cara pengambilan menggunakan consecutive sampling dalam kurun waktu satu bulan sejumlah 24 hari buka poliklinik.

Kriteria inklusi sampel adalah ;

1. Pasien dengan gingivitis ringan, sedang dan parah

2. Usia di atas 18 tahun.

3. Memiliki tekanan darah sistolik $\geq 120 \mathrm{mmHg}$ dan diastolik $\geq 80 \mathrm{mmHg}$

4. Bersedia menjadi responden

\section{Teknik Pengumpulan dan Analisa Data}

Data yang dikumpulkan adalah data primer berasal dari hasil pengukuran perdarahan gingival diperoleh Probe Bleeding Index dan tekanan darah yang diukur menggunakan tensimeter air raksa.

Data dianalisa menggunakan program komputer, diperoleh hasil analisis data menggambarkan proporsi serta kekuatan hubungan antara tingkat keparahan gingivitis dengan derajat hipertensi.

\section{Teknik Pengolahan Data}

Data primer yang diperoleh dari hasil pengukuran variabel penelitian dianalisa melalui proses pengolahan data sebagai berikut

- Editing (memeriksa), penyuntingan data yang dilakukan untuk menghindari kesalahan atau kemungkinan adanya kuesioner yang belum terisi.

- Coding dan scoring terhadap data hasil pengukuran indeks perdarahan gingival dan tekanan darah pasien.

- Cleaning data, sebelum analisis dilakukan pengecekan dan perbaikan data.

- Entry data, memasukkan data ke program komputer.

Analisis data terdiri dari analisis univariat dan bivariat

Analisis univariat, diperoleh gambaran dan

karakteristik variabel tingkat keparahan gingivitis serta derajat hipertensi.

Analisis bivariat, diperoleh hubungan antara tingkat keparahan gingivitis dengan derajat hipertensi menggunakan perhitungan uji statistic Spearman Corelation dan uji regresi linier.

\section{HASIL PENELITIAN DAN PEMBAHASAN}

\section{Hasil Penelitian}

Penelitian hubungan tingkat keparahan gingivitis dengan derajat hipertensi di Poli Gigi RSUP H Adam Malik Medan, dilakukan pengambilan data pada bulan September sampai dengan Oktober 2014.

Setelah dilakukan analisis data, hasil penelitian dapat dilaporkan sebagai berikut.
Karakteristik Responden

Tabel 4.1: Distribusi Frekuensi Karakteristik Responden Pasien Gingvitis di Poli Gigi RSUP H Adam Malik Medan Tahun 2014

\begin{tabular}{lccc}
\hline $\begin{array}{l}\text { Karakteristik } \\
\text { Reponden }\end{array}$ & Jumlah & $\%$ & $\sum \%$ \\
\hline Usia & & & \\
$39-55$ tahun & 34 & 56,7 & 56,7 \\
$56-72$ tahun & 26 & 43,3 & 100 \\
\hline Total & $\mathbf{6 0}$ & $\mathbf{1 0 0}$ &
\end{tabular}

Jenis Kelamin

\begin{tabular}{llll} 
Laki-laki & 14 & 23,3 & 23,3 \\
Perempuan & 46 & 76,7 & 100 \\
\hline Total & $\mathbf{6 0}$ & $\mathbf{1 0 0}$ & \\
\hline
\end{tabular}

Status Hormonal Perempuan

\begin{tabular}{llll} 
Belum Menopouse & 16 & 34,8 & 34,8 \\
Menopouse & 30 & 65,2 & 100 \\
\hline Total & $\mathbf{4 6}$ & $\mathbf{1 0 0}$ & \\
\hline
\end{tabular}

Tabel 4.1 menunjukkan bahwa jumlah responden lebih banyak berusia antara 39-55 tahun dibandingkan dengan responden berusia 56-72 tahun, mayoritas berjenis kelamin perempuan dan lebih banyak yang sudah menopause.

\section{Hipertensi}

Tabel 4.2.1: Distribusi Frekuensi Tekanan Darah Sistole Responden di Poli Gigi RSUP H Adam Malik Medan Tahun 2014

\begin{tabular}{|c|c|c|c|c|}
\hline $\begin{array}{l}\text { Tekanan } \\
\text { Sistole }\end{array}$ & Darah & Jumlah & $\%$ & $\sum \%$ \\
\hline $130 \mathrm{mmHg}$ & & 6 & 10,0 & 10,0 \\
\hline $140 \mathrm{mmHg}$ & & 14 & 23,3 & 33,3 \\
\hline $150 \mathrm{mmHg}$ & & 18 & 30,0 & 63,3 \\
\hline $160 \mathrm{mmHg}$ & & 16 & 26,7 & 90,0 \\
\hline $170 \mathrm{mmHg}$ & & 6 & 10,0 & 100 \\
\hline Total & & 60 & 100 & \\
\hline
\end{tabular}

Tabel 4.2.1 menunjukkan distri busi tekanan darah sistole responden lebih banyak pada $150 \mathrm{mmHg}$. 
Tabel 4.2.2: Distribusi Frekuensi Tekanan Darah Diastole Responden di Poli Gigi RSUP H Adam Malik Medan Tahun 2014

\begin{tabular}{|c|c|c|c|c|}
\hline $\begin{array}{l}\text { Tekanan } \\
\text { Diastole }\end{array}$ & Darah & Jumlah & $\%$ & $\sum \%$ \\
\hline $80 \mathrm{mmHg}$ & & 18 & 30,0 & 30,0 \\
\hline $90 \mathrm{mmHg}$ & & 32 & 53,3 & 83,3 \\
\hline $100 \mathrm{mmHg}$ & & 6 & 10,0 & 93,3 \\
\hline $110 \mathrm{mmHg}$ & & 2 & 3,3 & 96,7 \\
\hline $120 \mathrm{mmHg}$ & & 2 & 3,3 & 100 \\
\hline Total & & 60 & 100 & \\
\hline
\end{tabular}

Tabel 4.2.2 menunjukkan distribusi tekanan darah diastole responden lebih dari setengahnya pada $90 \mathrm{mmHg}$.

Tabel 4.2.3: Distribusi Frekuensi Derajat Hipertensi Responden di Poli Gigi RSUP H Adam Malik Medan Tahun 2014

\begin{tabular}{lccc}
\hline Derajat Hipertensi & Jumlah & $\mathbf{\%}$ & $\sum \%$ \\
\hline Pra & 6 & 10,0 & 10,0 \\
Derajat I & 32 & 53,3 & 63,3 \\
Derajat II & 22 & 36,7 & 100 \\
\hline Total & $\mathbf{6 0}$ & $\mathbf{1 0 0}$ & \\
\hline
\end{tabular}

Dari tabel 4.2.3 diatas diketahui, lebih dari setengah jumlah responden mengalami hipertensi derajat I, diikuti responden yang dengan hipertensi derajat II, dan hanya sebagian kecil terjadi pra hipertensi.

\section{Gingivitis}

Tabel 4.3: Distribusi Frekuensi Responden dengan Gingivitis di Poli Gigi RSUP H Adam Malik Medan Tahun 2014

\begin{tabular}{lccc}
\hline Kriteria Gingivitis & Jumlah & $\mathbf{\%}$ & $\sum \%$ \\
\hline Ringan & 30 & 50,0 & 50,0 \\
Sedang & 24 & 40,0 & 90,0 \\
Parah & 6 & 10,0 & 100 \\
\hline Total & $\mathbf{6 0}$ & $\mathbf{1 0 0}$ &
\end{tabular}

Berdasarkan tabel 4.3 dapat dilihat bahwa setengah dari jumlah responden mengalami gingivitis ringan, menyusul esponden dengan gingivitis sedang, dan hanya sebagian kecil responen yang mengalami gingivitis parah.
Hubungan Gingivitis dengan Hipertensi

Tabel 4.4.1: Hubungan Tingkat Keparahan Gingivitis dengan Derajat Hipertensi di Poli Gigi RSUP H Adam Malik Medan Tahun 2014

\begin{tabular}{|c|c|c|c|c|c|c|c|c|c|}
\hline \multirow{3}{*}{$\begin{array}{l}\text { Tingkat } \\
\text { Keparahan } \\
\text { Gingivitis }\end{array}$} & \multicolumn{6}{|c|}{ Derajat Hipertensi } & \multirow{2}{*}{\multicolumn{2}{|c|}{ Total }} & \multirow{3}{*}{$\begin{array}{c}\mathbf{P} \\
\text { Value }\end{array}$} \\
\hline & \multicolumn{2}{|c|}{ Pra- } & \multicolumn{2}{|c|}{ Derajat I } & \multicolumn{2}{|c|}{ Derajat II } & & & \\
\hline & $\mathbf{n}$ & $\%$ & $\mathbf{n}$ & $\%$ & $\mathbf{n}$ & $\%$ & $\mathbf{n}$ & $\%$ & \\
\hline Ringan & 6 & 100,0 & 16 & 53,3 & 8 & 26,7 & 30 & 100,0 & \\
\hline Sedang & 0 & 00,0 & 14 & 58,3 & 10 & 41,7 & 24 & 100,0 & \\
\hline Parah & 0 & 00,0 & 2 & 33,3 & 4 & 66,7 & 6 & 100,0 & 0,013 \\
\hline Total & 6 & 10,0 & 32 & 53,3 & 22 & 36,7 & 60 & 100,0 & \\
\hline
\end{tabular}

Tabel 4.4.1 memperlihatkan bahwa responden dengan gingivitis ringan terbanyak mengalami prahipertensi. Responden dengan gingivitis sedang, lebih banyak mengalami hipertensi derajat I, diikuti hipertensi derajat II. Sedangkan responden dengan gingivitis parah lebih banyak mengalami hipertensi derajat II.

Berdasarkan hasil uji Spearman Corelation dengan tingkat kepercayaan $95 \%$ didapat nilai $\mathrm{p}=0,013$ maka terbukti ada hubungan yang bermakna antara tingkat keparahan gingivitis dengan derajat hipertensi.

Tabel 4.4.2: Analisis Hubungan dan Regresi Tingkat Keparahan Gingivitis dengan Derajat Hipertensi di Poli Gigi RSUP H Adam Malik Medan Tahun 2014

\begin{tabular}{|c|c|c|c|c|}
\hline Variabel & $\mathbf{r}$ & $\mathbf{R}^{2}$ & $\begin{array}{c}\text { Persamaan } \\
\text { Garis }\end{array}$ & $\begin{array}{c}\mathbf{P} \\
\text { Value }\end{array}$ \\
\hline $\begin{array}{l}\text { Tingkat } \\
\text { Keparahan } \\
\text { Gingivitis }\end{array}$ & 0,336 & 0,113 & $\begin{array}{c}\text { Derajat } \\
\text { Hipertensi: } \\
\begin{array}{c}1,758+0,318^{*} 1 \\
=2,076\end{array}\end{array}$ & 0,009 \\
\hline
\end{tabular}

Dari tabel 4.4.2 menunjukkan antara tingkat keparahan gingivitis dengan derajat hipertensi menunjukkan hubungan yang sedang $(r=0,336)$ dan berpola positif.

Dengan nilai koefisien determinasi 0,113 maka persamaan garis regresi hanya $11,3 \%$ variasi derajat hipertensi. Dari uji statistik terdapat hubungan dan regresi yang bermakna antara tingkat keparahan gingivitis dengan derajat hipertensi.

Dari persamaan garis maka dapat diprediksi bahwa pada tingkat gingivitis ringan $(\mathrm{PBI}=1)$ akan terjadi hipertensi derajat I (140-159/90-99 $\mathrm{mmHg})$

\section{PEMBAHASAN}

\section{Karakteristik Responden}

Subyek penelitian menunjukkan bahwa prosentase gingivitis lebih banyak berusia dibawah 55 tahun dibandingkan dengan usia diatas 55 tahun. Penelitian Hugoson dan Jordon pada tahun 1982 dan penelitian Zang dkk pada tahun 2010 di Cina menunjukkan sedikit berbeda hasil, yaitu prosentase 
gingivitis tertinggi terjadi pada usia lebih dari 59 tahun diikuti kelompok usia 45-59 tahun.

Usia terendah subyek penelitian ini adalah 39 tahun, berbeda dengan penelitian yang dilakukan tahun 2009 oleh Lang dkk menunjukkan bahwa prosentase gingivitis tertinggi terjadi pada usia lebih dari 26 tahun, artinya bahwa terjadinya gingivitis bukan karena faktor usia.

Mayoritas subyek penelitian berjenis kelamin perempuan dan lebih banyak yang sudah menopouse, Hal ini terjadi sesuai teori bahwa perubahan hormonal yang terjadi pada masa pubertas, hamil, dan menopause diatas usia 55 tahun.

Jika ditinjau dari jenis kelamin, hasil penelitian menunjukkan jumlah yang tidak seimbang. Jumlah yang tidak seimbang ini disebabkan karena sulit memperoleh subyek laki-laki. Hal ini kemungkinan karena mereka tidak ada kesempatan berobat ke Poli Gigi pada jam kerja, dibandingkan dengan subyek perempuan. Sebagai ibu rumah tangga mereka dapat menyempatkan diri berobat disela-sela waktu melakukan pekerjaan rumah tangganya

Hal ini berbeda dengan penelitian oleh Yiming dkk (2010) menunjukkan bahwa subyek penelitian berjeniskelamin laki-laki yang mengalami gingivitis secara signifikan lebih banyak dibandingkan dngan subyek perempuan.

\section{Gingivitis}

Berdasarkan hasil penelitian dapat dilihat bahwa subyek penelitian yang memiliki gingivitis ringan dan sedang menunjukkan jumlah yang seimbang, sedangkan pasien dengan gingivitis parah hanya sebagian kecil dari jumlah responden. Keadaan ini dapat disebabkan karena kebersihan mulut yang buruk. Koloni bakteri dalam rongga mulut membentuk biofilm sehingga resisten baik secara fisik maupun kimia. Menjaga kebersihan mulut dan gigi dengan menyikat gigi dengan teratur sesudah makan dan menjelang tidur akan mencegah berkembangnya bakteri.

Hal ini sependapat dengan hasil penelitian Theilade dkk tahun 1966 menyebutkan bahwa etiologi utama gingivitis adalah plak dan kalkulus. Kebanyakan pasien yang mengalami gingivitis mempynyai akumulasi kalkulus dan plak sehingga dapat memperburuk oral hygiene.

Pada penelitian ini tidak diteliti secara klinis namun hanya berdasarkan penjelasan subyek penelitian rata-rata telah menyikat gigi setiap hari secara teratur.

\section{Hipertensi}

Hasil penelitian menunjukkan bahwa lebih dari setengah jumlah responden menderita hipertensi derajat I, sepertiganya mengalami hipertensi derajat II dan sebagian kecil mengalami pra-hipertensi. Kondisi ini dapat disebabkan karena hipertensi adalah peningkatan tekanan darah arteri yang bersifat asimtomatik dalam beberapa tahun. Pada awalnya pasien tidak merasakan gejala subyektif, seperti sakit kepala bagian oksipital, penglihatan kabur, telinga berdengung, pusing, sering kesemutan pada tangan dan kaki.
Hal lain yang belum dipahami oleh masyarakat bahwa hipertensi merupakan faktor risiko utama pada stroke, penyakit jantung kongestif, gagal jantung, atau gagal ginjal. Terlebih lagi masyarakat belum menyadari bahwa gingivitis atau perdarahan gingival berhubungan dengan perubahan sistemik. Pada beberapa penyakit sistemik, perubahan hormonal, pemakaian obat-obatan antihipertensi, anti konvulsan dapat terjadi pembengkakan gingival sekunder menyebabkan perdarahan gingival.

\section{Hubungan Gingivitis dengan Hipertensi}

Responden dengan gingivitis ringan terbanyak mengalami pra-hipertensi, responden dengan gingivitis sedang lebih banyak mengalami hipertensi derajat I, diikuti hipertensi derajat II. Sedangkan responden dengan gingivitis parah lebih banyak mengalami hipertensi derajat II.

Pada penelitian ini, sewaktu dilakukan pengukuran tekanan darah, pasien telah mengkonsumsi obat anti hipertensi. Data ini dapat diduga bukan merupakan data yang sebenarnya karena hampir seluruh responden adalah pasien dengan diagnosa hipertensi grade I, II, dan hipertensi terkontrol yang sudah menggunakan obat anti hipertensi. Untuk mendapatkan data yang sebenarnya sebaiknya pengukuran hipertensi dilakukan sebelum pasien minum obat anti hipertensi secara rutin. Oleh karenanya hasil penelitian kemungkinan akan berbeda dengan data yang sebenarnya.

Berdasarkan hasil uji Spearman Corelation dengan tingkat kepercayaan $95 \%$ didapat nilai $\mathrm{p}=0,013$ maka terbukti ada hubungan yang bermakna antara tingkat keparahan gingivitis dengan derajat hipertensi.

Dari semua pasien gingivitis. baik gingivitis ringan maupun sedang, jumlah terbanyak mengalami hipertensi derajat I. Hal ini sesuai dengan hasil uji statistik bahwa hasil penelitian ini menunjukkan adanya hubungan yang bermakna antara tingkat keparahan gingivitis dengan derajat hipertensi. Hasil penelitian ini berbanding terbalik dengan hasil penelitian Kumar dkk tahun 2012 menyatakan bahwa pasien hipertensi dapat mengalami perdarahan gingival sebesar 85,38\%. Kumar dkk menjelaskan bahwa terdapat pelebaran pembuluh darah pada pasien hipertensi yang meminum obat anti hipertensi sehingga apabila terjadi stimulasi maka gingival akan mudah terjadi perdarahan.

Dengan adanya hubungan yang bermakna antara tingkat keparahan gingivitis dengan derajat hipertensi, maka peneliti berpendapat bahwa gingivitis harus mendapat pehatian seksama untuk mencegah hipertensi Termasuk sejumlah kondisi oral seperti anatomi dan posisi gigi, kuantitas dan kualitas pada sekeliling gingiva, panjang junctional epithelium, impaksi makanan, dan aplikasi ortodonti.

Malposisi gigi juga perlu diperhitungkan sebagai penyebab gingivitis. Malposisi gigi dapat menyebabkan akumulasi plak sehingga terjadi inflamasi pada gingiva.

Diet gula tinggi juga berperan penting dalam meningkatkan pertumbuhan bakteri. Seseorang yang mengkonsumsi diet tinggi gula dalam periode tiga minggu 
akan lebih rentan terjadi gingivitis dibandingkan dengan diet rendah gula.

Hasil uji regresi penelitian ini memperoleh hasil terdapat hubungan yang sedang dan berpola positif antara tingkat keparahan gingivitis dengan derajat hipertensi, artinya semakin tinggi tingkat keparahan gingivitis maka semakin tinggi derajat hipertensi. Namun, dari persamaan garis regresi hanya 11,3\% variasi derajat hipertensi berarti pesamaan garis tersebut kurang baik untuk menjelaskan tingkat keparahan gingivitis.

Dari uji statistik terdapat hubungan dan regresi yang bermakna antara tingkat keparahan gingivitis dengan derajat hipertensi. Adapun prediksi antara tingkat keparahan gingivitis dengan derajat hipertensi adalah, bahwa gingivitis ringan akan terjadi hipertensi derajat I .

Gingivitis dan periodontitis merupakan sumber kuman-kuman patogen, antigen kuman, endotoksin, sitokin peradangan yang berperan di dalam aterogenesis dan proses thromboembolik. Keadaan ini merupakan peningkatan faktor risiko pembentukan plak ateromatosa yang dapat memengaruhi ketebalan pembuluh darah dan menyempitkan pembuluh darah yang bersangkutan. Plak ateromatosa dapat mengalami emboli dan ruptur sehingga mengakibatkan oklusi parsial atau total dari lumen pembuluh darah distal dan menjadi faktor presipitasi terjadinya stroke atau infark miokardial.

Pendapat bahwa infeksi oral atau periodontal dapat memengaruhi kesehatan tubuh secara sistemik sering dikemukakan didalam laporan penelitian terdahulu. Seperti diungkapkan kembali oleh DeStefano dan Beck yang menyatakan bahwa penyakit periodontal dapat menjadi risiko independen bagi keadaan sistemik khususnya didalam hal terjadinya penyakit kardiovaskuler. Proses patologis yang mendasari kelainan ini adalah aterosklerosis yang terjadi akibat adanya penimbunan fibrolipid atau plak ateromatosa pada dinding dalam pembuluh darah berukuran sedang dan besar.

\section{KESIMPULAN DAN SARAN}

\section{Kesimpulan}

1. Proporsi gingivitis terhadap hipertensi menunjukkan lebih setengah dari pasien gingivitis ringan berhubungan dengan hipertensi derajat I.

2. Proporsi gingivitis terhadap hipertensi menunjukkan lebih setengah dari pasien gingivitis sedang berhubungan dengan hipertensi derajat I.

3. Proporsi gingivitis terhadap hipertensi menunjukkan lebih banyak pasien gingivitis parah berhubungan dengan hipertensi derajat II.

4. Terdapat hubungan yang bermakna antara tingkat keparahan gingivitis dengan derajat hipertensi.

5. Tingkat keparahan gingivitis dengan derajat hipertensi menunjukkan hubungan yang sedang dan berpola positif.

6. Dapat diprediksi bahwa gingivitis ringan akan terjadi hipertensi derajat I.

\section{Saran}

1. Agar petugas kesehatan selalu memberikan informasi terhadap pasien di Poli Gigi RSUP $\mathrm{H}$ Adam Malik Medan tentang adanya hubungan yang bermakna antara gingivitis dengan hipertensi.

2. Agar masyarakat melakukan pemeriksaan dan perawatan gigi secara teratur dari sejak dini untuk mencegah terjadinya hipertensi.

3. Agar hasil penelitian dapat digunakan sebagai sumber data bagi peneliti lain untuk penelitian lanjutan dengan topik yang sama

4. Agar hasil penelitian dapat dijadikan sumber referensi di Perpustakaan Terpadu Politeknik Kesehatan Kemenkes Medan.dan RSUP H Adam Malik Medan

\section{DAFTAR PUSTAKA}

American Medical Association, 2003, Seventh Report of the Joint National Committee on Prevention, Detection, Evaluation, and Teatment of High Blood Pressure, Hypertensive

Dalimunthe SH. 2005. Periodontia USU Press

Departemen Kesehatan, 2004, Survei Kesehatan Nasional, Laporan Departemen Kesehatan RI, Jakarta.

Doniger SB. 2005, Hypertension the silent killer, Registered Dental Hygienist.

Iqbal M. 2011. Review clinical perspective on the management of hypertension. Indian Journal of Clinical Medicine.

Kumar P, et al, 2012 .Oral Manifestations in hypertension patients : A clinical study. Journal of Oral Maxillofacial Pathology

Lang NP, et al, 2009, Gingivitis as Risk Factor in Periodontal Disease, Journal of Clinical Periodontology

Pintauli S,. Hamada T , 2008, Menuju Gigi dan Mulut Sehat Pencegahan dan Pemeliharaan, USU Press, Medan.

Sikkerimath SB, DNSV R.(2010) Study on the prevalence of hypertension in dental outPatient population. Journal of Indian Academy of Oral Medicine and Radiology

Theilade E, Wright WH, 1966, Jensen SB, Experimental Gingivitis in a Man A Longitudinal Clinical and Bacteriological Investigation, Journal of Periodontology

Wangsarahardja, Kartika, 2005, Penyakit Periodontal sebagai Faktor Risiko Penyakit Jantung Koroner, Universitas Medicina

Yiming Li, et al, 2010, Prevalence and Saverity of Gingivitis in American Adults, American Journal of Dentistry

Zhang J, et al, 2010, Severity and Prevalence of Plaqueinduced Gingivitis in The Chinese Population, Compendium. 